\title{
Gender and Sexuality in the Poetry of Sylvia Plath
}

\author{
Alita Fonseca Balbi \\ Mestranda em Literaturas de Expressão Inglesa / UFMG
}

\begin{abstract}
This paper analyses the manner in which Sylvia Plath's poems portray gender relations and, more specifically, how the construction of gender based on hierarchy and inequality becomes an obstacle to harmonious relationships between people. In the poems analyzed, the ideals of love and intimacy are always driven away because of gender inequality that still today continues to serve as the basis to interpersonal relations. In this context, Plath's poetry depicts sexuality as a central tool in the perpetuation of male dominance and female submission, a fact that makes the relations between men and women even more difficult.
\end{abstract}

\section{KEYWORDS}

Poetry, gender, sexuality

In his study on the development of intimacy in the history of our society, Anthony Giddens ${ }^{1}$ argues that sexuality is one of, if not the major, "malleable feature of the self," "a prime connecting point between body, self-identity and social norms." Hence, a discussion on interpersonal relations, which are also social relations, cannot avoid the sexual aspects that are at work in constructing people's identities. In Plath's poems sexuality appears as an oppressive manifestation of social demands, and the perpetuation of patriarchal ideology is directly related to the way oppressive notions of sexuality are imposed. Contrary to the idea that sexual liberalization means a step ahead towards individual freedom, Plath's poetry presents a negative view on the place and importance

${ }^{1}$ GIDDENS. The transformation of intimacy: sexuality, love and eroticism in modern societies, p. 15. 
sexuality has acquired throughout twentieth-century's culture. Rather than a form of expressing oneself, sexuality is seen as controlling subjectivity more than ever, and, moreover, as limiting and predefining people's relations with each other. Hence, this paper presents a reading on the way social discourses on sexuality in a culture of gender inequality is seen to influence, mainly negatively, the subject's individuality and the interpersonal relations of intimacy in Plath's poems.

In Plath's poetry sexuality appears as the means through which people try to express their individuality but fail to do so. These attempts are frustrated because even though sexuality is usually thought of as private and subjective it is in fact shaped by forces external to the individual. Angela Carter argues that even though sexual intercourse is usually understood as an intimate act and thought of as capable of revealing people's "true selves" ${ }^{2}$ to one another, it is in fact the form of personal interaction that best reflects social norms. For instance, if in a society men are ideologically considered superior to women and are prone to be active in opposition to women's submission, that will be reflected in people's sexuality, and hence, in their relationships with each other.

The idea of sexuality as a construction and not as an expression of individuality appears in the poems through a constant use of irony and performance. In Plath's "Lesbos" ${ }^{3}$ men and women try to copy the models of sexual behavior they see in movies, and in this scenery of mimicry and superficial enactments the reworking of sexual stereotypes become an important tool for criticizing the limited ways in which sexuality is defined. After all, sexuality is constructed through stereotypes, such as the hunk and the fag for men, and the saint and the whore for women. Nevertheless, even though the poems show the speakers' attempt to escape such definitions, they frequently present a sense of entrapment, as if despite the speakers' knowledge of sexuality's oppression they cannot avoid being victims all the same.

Sexuality, then, assumes a threatening character because serving the ideology of gender hierarchy it becomes an instrument to physically and psychologically impose one's will on others. Plath's poems represent this dynamics by portraying female speakers who are afraid and resentful of the sexual violence represented by men. In relation to sexual violence as a form of ideological mastery, Carter argues:

\footnotetext{
${ }^{2}$ CARTER. The sadeian woman: an exercise in cultural history, p. 9.

${ }^{3}$ PLATH. Collected poems, p. 228.
} 
Violence, the convulsive form of the active, male principle, is a matter for men, whose sex gives them the right to wound one another because that only makes us [women] fear them more, that they can give and receive pain like the lords of creation(...) [V]iolence has always been the method by which institutions demonstrate their superiority. ${ }^{4}$

Male capacity of sexually inflicting pain is recurrent in Plath's poems, and it is seen as one of the main reasons for the increasing emotional gap between men and women. In poems such as "Virgin in a Tree" and "Fever $103^{\circ}$," Plath addresses the constant repression of women's sexuality, which has served for a long time as means to deprive women of autonomy over their bodies and subjectivity. In this sense, her poetry exposes the negative effects sexual violence and gender hierarchy impose on the relations between people.

Similarly to Carter, Laura O’Toole argues that sexuality has been used throughout history and in different societies as a powerful and strong mechanism of power control, especially in the subjugation of women by men. According to O’Toole:

Much of the violence in contemporary society serves to preserve asymmetrical gender systems of power. For example, compulsory aggression as a central component of masculinity serves to legitimate male-on-male violence, sexual harassment as a means of controlling the public behavior of women, gay and lesbian bashing, and rape as a standard tool in war, in prisons, and in too many intimate relationships. ${ }^{5}$

When sexuality is used as a tool of oppression, as O'Toole argues, the body becomes one of the main objects of control and violence. ${ }^{6}$ In this sense, a reading concerning gender relations has to discuss the place of sexuality and the sexual body that are at play. It may be argued that every body is sexual, since "sex" may be understood as one of the biological components intrinsic to a person's body. However, for analytic purposes it is important to understand that in the context of gender criticism, and especially in the context of Plath's poetry, the body signifies the main locus of gender politics. $^{7}$

Even though there has been advances regarding sexual stereotypes, in Plath's poetry they are much present and heavily define the society the characters live in and how

\footnotetext{
${ }^{4}$ CARTER. The sadeian woman: an exercise in cultural history, p. 25.

${ }^{5}$ O'TOOLE; SHIFFMAN. Preface: conceptualizing gender violence, p. xi-xiv.

${ }^{6}$ See FOUCAULT. The history of sexuality: an introduction, p. 26.

${ }^{7}$ See BUTLER. Bodies that matter: on the discursive limits of sex, p. 54.
} 
they see their places in it. Because it is the source of oppressive impositions upon individuality, sexuality is seen in her poetry as something artificial and lacking sensuous character. Rather than bringing emotional satisfaction, sexuality is often related to the matter of how much control (or lack of it) the subject has upon his or her own individuality. Autonomy in relation to one's own sexuality is met with an increasing number of public information regulating upon the matter. Drawing from Lawrence Birken's work on sexuality and the rise of consumer society, Joseph Bristow argues that "an increasing emphasis on autonomy met with a corresponding response for more regulatory laws to control the potential anarchy unleashed by the proliferation of individual desires”. ${ }^{8}$ As Michel Foucault argues, sex has become an issue connecting the individual and the state, the private and the public: "Between the state and the individual, sex became an issue, and a public issue no less; a whole web of discourses, special knowledges, analyzes, and injunctions settled upon it."9 To understand the way a society deals with sexuality is to understand the normative demands that fall upon individuals and their relations with each other.

Foucault's main concern is how the "will to knowledge" that dominates our society serves both as a "support" and as an "instrument" to "discursive productions" of the "truth about sex". ${ }^{10}$ More than that, the regulatory power that permeates such discourses "reach the most tenuous and individual modes of behavior" and "penetrates and controls everyday pleasure". ${ }^{11}$ Having in mind the influences such powers have on people's individuality, it is possible to see how Plath's poetry expose sexuality not as an expression of subjectivity but as a reflection of a culture that works towards a increasing regulation of desire and of identities.

\section{WHAT IS SEX?}

Still today there is a general reductionist belief that anatomy contains the answer to everything related to people's sexuality. Studies on gender expose the growing number of biological explanations for people's behavior and tastes. It has been argued, however, by the humanities especially, that these "mappings" have served purposes beyond what

\footnotetext{
${ }^{8}$ BRISTOW. Sexuality, p. 57.

${ }^{9}$ FOUCAULT. The history of sexuality: an introduction, p. 26.

${ }^{10}$ FOUCAULT. The history of sexuality: an introduction, p. 11.

${ }^{11}$ FOUCAULT. The history of sexuality: an introduction, p. 11.
} 
they initially set out to achieve. ${ }^{12}$ Rather than understanding the way people behave, these scientific reliance on anatomy leads instead to an increasing regulation of it, resulting in a classification and imposition of what is normal and what is not.

One of the criticisms gender studies have raised towards biological determinism is the complicated relation between gender and sexuality. Despite a long-term association, "gender" and "sex" are usually seen in gender studies as two different concepts. The difference lies in the complex relation between "the performance of gender, as opposed to the biology of sex", 13 a distinction that points to the fact that a person may present gender features that are not socially compatible with one's sexual organs - for example, a person may act and be accepted as a woman in society even though this same person has a male sexual organ. Some critics affirm the possibility of complete separation between sex and gender. Robert Stoller, for instance, argues that "while sex and gender seem to common sense to be practically synonymous and in everyday life to be inextricably bound together... the two realms (sex and gender) are nor inevitably bound in anything like a one-to-one relationship, but each may go in its quite independent way". ${ }^{14}$ Teresa de Lauretis, in her turn, sees gender as "a symbolic system or system of meanings that correlates sex to cultural contents according to social values and hierarchies”. ${ }^{15}$ Stoller's and de Lauretis's views are incompatible because if gender happens to be a connector between sex and culture then it cannot be seen as a separate concept.

Judith Butler argues that even though different, gender and sex cannot be understood separately in our culture. In this sense, she positions herself against the sex/gender binary altogether:

Taken to its logical limit, the sex/gender distinction suggests a radical discontinuity between sexed bodies and culturally constructed genders. Assuming for a moment the stability of binary sex, it does not follow that the construction of "men" will accrue exclusively to the bodies of males or that "women" will interpret only female bodies. ${ }^{16}$

For Butler, sexuality is the means through which gender norms "produce the

\footnotetext{
${ }^{12}$ See FAUSTO-STERLING. Sexing the body: gender politics and the construction of sexuality.

${ }^{13}$ WOLFREYS. Critical keywords in literary and cultural theory, p. 75.

${ }^{14}$ STOLLER. Sex and gender: on the development of masculinity and femininity, p. xiii.

${ }^{15}$ DE LAURETIS. Technologies of Gender: essays on theory, film, and fiction, p. 5.

${ }^{16}$ BUTLER. Bodies that matter: on the discursive limits of sex, p. 6-7.
} 
bodies it governs", ${ }^{17}$ meaning that the body is understood through "regulatory practices”18 that reinforce pre-established concepts of gender. Addressing the "regulatory" power of the sexed body, Carter argues that the reason why sexual organs became the highest representation of gender difference is because they are the crudest form of representing it. ${ }^{19}$ The body, then, appears as means of defining people's roles in a society based on well defined gender roles. Even though accusing the importance of the body's material visibility, its “matter,” Butler, influenced by Foucault's structuralist view of sexuality, argues that our understanding of the body nonetheless is a product of normative gender discourses: "what constitutes the fixity of the body, its contours, its movements, will be fully material, but materiality will be rethought as the effect of power, as power's most productive effect." ${ }^{20}$ Hence, the visibility of the body, and of the physical differences between the sexes, becomes an ideal repository of the discourse of gender inequality.

The body has been the main focus of science in the study of sexuality. However, the advance of science has served dubious purposes when it comes to sexual politics. Biology has been used as a tool to justify gender hierarchy. Nowadays, a scientific discovery is something proved and reliable. Moreover, science has created its own dogmas and spreading its own set of ideologies, some beneficial, some quite oppressive. Still today, a number of efforts are made in order to see in people's biological constitution explanations and defining elements to their behavior. In Sexing the Body, Anne FaustoSterling investigates the development of scientific studies on sexuality and connects their findings to the shaping of social discourses on gender. According to Fausto-Sterling:

Scientists struggled with nomenclature, classification, and measurement for a variety of reasons. In scientific culture, accuracy and precision have high moral status, and as good scientists, using the highest standards of their trade, endocrinologists wanted to get it right (...) "[I]t" was a loaded term - denoting a variety of social understandings of what it meant in the years 1920 to 1940 to be male or female. Whatever "it" was defined both biological and social normality. ${ }^{21}$

Fausto-Sterling's research concludes that even though scientists have been aiming

\footnotetext{
${ }^{17}$ BUTLER. Bodies that matter: on the discursive limits of sex, p. 1.

${ }^{18}$ BUTLER. Bodies that matter: on the discursive limits of sex, p. 2.

${ }^{19}$ CARTER. The sadeian woman: an exercise in cultural history, p. 5.

${ }^{20}$ BUTLER. Bodies that matter: on the discursive limits of sex, p. 2.

${ }^{21}$ FAUSTO-STERLING. Sexing the body: gender politics and the construction of sexuality, p. 191.
} 
at a high level of accuracy regarding human sexuality, contradictions emerge to break the precision of preconceived notions about the matter. What studies on sexuality seem to indicate is that, instead of accuracy, human behavior is driven by the most diverse, and even unknown, forces.

According to Joseph Bristow, the first appearance of the word "sexuality" in the English language dates to 1836, to William Cowper, in what happened to be a study of the reproduction of plants. ${ }^{22}$ One thing this information reveals is that it is quite a recent subject, at least when it comes to academic research, and that it is not as ingrained in people's nature as it is usually thought of today. The rise of the studies on sexuality has caused tremendous changes in society's and individual's behavior, and it is possible to affirm that such changes are still felt today. The institutionalization of sexuality, discussed by Foucault and others, has a central role in today's society, which presents a general belief that sexuality defines the individual's happiness, idea that is perpetuated by a number of advertisement and guides to “improve” one's sexual life. ${ }^{23}$

Foucault makes it clear that before being private and intimate, sexuality is cultural and is public ${ }^{24}$. In fact, sexuality may be the place, as Carter argues, in which social norms manifest themselves more fully when it comes to the definition of gender roles. ${ }^{25}$ This normative quality of sexuality goes far back in history and has served different purposes of social integration and control, but never has the issue received more attention than in our present society. ${ }^{26}$ According to Foucault, what appears to us to be a step forward in the liberalization of sexual practices, by talking about it more, is in fact another, and maybe even more effective, form of controlling what is being done and how it is being done. ${ }^{27}$ In this sense, a critical understanding of sexuality and of "the way sex is' put into discourse, ${ }^{, 28}$ is intrinsically related to the shaping of subjectivity and the tendency of standardizing interpersonal relations.

Since, in Plath's poems, sexuality reflects how social norms control and

\footnotetext{
${ }^{22}$ BRISTOW. Sexuality, p. 5.

${ }^{23}$ BRISTOW. Sexuality, p. 12.

${ }^{24}$ FOUCAULT. The history of sexuality: an introduction, p. 26.

${ }^{25}$ CARTER. The sadeian woman: an exercise in cultural history, p. 10.

${ }^{26}$ BRISTOW. The history of sexuality: an introduction, p. 12.

${ }^{27}$ FOUCAULT. The history of sexuality: an introduction, p. 11.

${ }^{28}$ FOUCAULT. The history of sexuality: an introduction, p. 11.
} 
manipulate individuality, it is in the field of sexuality that an attempt to escape manipulation and gain control over one's subjectivity happens. Plath's poems address different "knowledges" that are seen as perpetuating essentialist views on gender and sexuality, such as stereotypes, prejudices, and essentialist scientific discourse. To question these discourses is to question their power and to go against the oppression they impose, and different poems by Plath portray female speakers' attempts to deny stereotypes of female of sexuality.

\section{Old WHORE PETTICOAT}

"Pure,” the speaker in Plath's "Fever 103"” asks, “[w]hat does that mean?”. The question embodies the conflict enacted in the poem, which is a woman's attempt to get rid of the sexual stereotypes that have been imposed upon the female gender, more specifically the saint/whore dichotomy. History, religion and social conventions, all sources of oppression, are burned through the speaker's process of "purification." In a kind of Dantian journey, the speaker begins her narrative in hell and ends in "Paradise." In this process, she goes from a place of promiscuity to a state of such purity that no one can touch her and all her "selves" dissolve. The poem questions whether it is possible to get rid of stereotypes and assume control of one's own sexuality and individuality. Is the negation of the body the only escape to social impositions on sexuality?

According to Christina Britzolakis, "Fever 103 " reflects a woman “flickering” between empowering and oppressive views of her own sexuality, which are related to the way male desire constructs the female identity. For Britzolakis, the speaker is "plotting a transcendence parodically redefined as an erotic, indeed orgasmic event". ${ }^{29}$ In the poem, sexuality is abstracted through references to female sexual stereotypes. Figure by figure, the speaker "burns" the different social stigmas that fall upon her as a woman. Her journey is a journey of "purification”, a stripping of oppressive identities ("my selves dissolving, old whore petticoat”). The ending is enigmatic, for why do the selves dissolve and the petticoat remains? Petticoats are usually associated with prostitutes, who used them in the past. Even though it is used to hide the female sex, the petticoat also suggests the same thing it hides, becoming an object of sexual enticement. In this sense, the petticoat embodies the saint/whore dichotomy the speaker wants to get rid of throughout

\footnotetext{
${ }^{29}$ BRITZOLAKIS. Sylvia Plath and the theatre of mourning, p. 141.
} 
the poem.

When it comes to the interrelation between body and gender roles, Butler argues that normative discourses on "sex" govern the way people conceive their own bodies and each others', and it is a "regulatory ideal” whose materialization happens "through certain highly regulated practices". ${ }^{30}$ Drawing from Foucault, Butler also works with the hypothesis of sexuality being an instrument of manipulation of people's individualities. Nevertheless, Butler does not present a deterministic view on the relation between regulatory discourses and sexuality because in the same way the body is subject to "regulated practices" it is also passive of subversive forms of interpreting and enacting social roles. ${ }^{31}$ In this context, the stripping of sexual identities and the burning of the body in Plath's poems can be read as a subversive appropriation of regulatory discourses.

The main problem is that Plath's poem does not offer a way out for her speaker to escape oppressive identities. She burns the stereotypes, but her body also dissolves in the end. Hence, in Plath's poems, sexuality has a duplicitous role: it is a source of freedom but also of oppression. There is an attempt from Plath's female speakers to assume a more assertive control of their own sexuality, but male desire keeps appearing in the form of threatening figures, while the female one is incapable of being imposed in a society in which women are subjugated to a male-centered ideology. In poems such as "The Jailer ${ }^{\text {32 }}$ the female speakers are aware of being caught in an ensnaring net of male sexual and ideological dominance, nevertheless they are unable to escape it. Such threat that pervades a male-dominated world is one of the reasons why Plath's female speakers assume a very negative view in relation to their own bodies.

Kathleen Lant describes the cultural differences between male and female nakedness and how it interferes in Plath's writing of poetry:

The unclothed male body - in terms of the dominant figurative systems of Western discourse - powerful in that it is sexually potent, sexually armed; the naked female body is - again, in terms of the figurative systems which dominate this period - vulnerable in that it is sexually accessible, susceptible to penetration, exploitation, rape, pregnancy. ${ }^{33}$

The fact that female anatomy is so susceptible to male sexual violence causes a

\footnotetext{
${ }^{30}$ BUTLER. Bodies that matter: on the discursive limits of sex, p. 1.

${ }^{31}$ BUTLER. Bodies that matter: on the discursive limits of sex, p. 2.

${ }^{32}$ PLATH. Collected poems, p. 226.

${ }^{33}$ LANT. The big strip tease: female bodies and male power in the poetry of Sylvia Plath, p. 626.
} 
resentment in women's voices that inhabit Plath's poetic world. According to Lant, it is a matter of thinking their bodies are "inadequate" to the freedom men experience to explore the world without being constantly afraid. Lant also argues that, contrary to what happens in several poems written by men (she cites Whitman, Lowell, to name a few), nakedness in Plath does not represent freedom and power. Instead, it reveals the female self as "unworthy, and - ultimately - vulnerable rather than ascendant”. ${ }^{34}$ For Lant, sexuality and gender hierarchy in Plath's poetry are deeply connected. Drawing from sociological studies on rape, Lant argues that biology has historically rendered the female body as passive to violence, specifically from the male/active body.

The idea that men have the anatomical capacity of imposing themselves sexually on women is important in Lant's reading, which basis itself on studies on rape to explain the sense of fear and danger that assails female nakedness in Plath's poetry. It is important to remember Butler's view on the importance of the body in the construction of the subject's sexuality for, although the male sexual threat is physical in its manifestation, its most damaging effects are the psychological ones. Hence, sexual threat becomes one of the main impediments for the achievement of a more autonomous female consciousness.

The problem, however, in Plath's poems is not exclusively the sexual "frailty" of women's bodies, but the fact that there is always a male figure threatening the possibility of freedom, as the fearful figure of the "surgeon" in "The Bee Meeting" and the mysterious male watcher in "Stings". This relationship of male gazer and the woman as object of the gaze reflects the way Plath's speakers are constantly concerned with how other people, mainly men, conceive their image, their third person selves.

Since Laura Mulvey’s “Visual Pleasure and Narrative Fiction”, a great attention has been paid to women's body as the object of male gaze in cinema and furthermore in culture as a whole. After all, it is the woman's body that is on display and eroticized in front of the camera: "In a world ordered by sexual imbalance, pleasure in looking has been split between active/male and passive/female. The determining male gaze projects its phantasy on to the female figure which is styled accordingly."35 The article exposes how ideal representations are constructed by media and how these representations influence the way people see and relate to each other. Mulvey's argument also opens the path to a more complex matter, which is the possibility of imposing meaning through the

\footnotetext{
${ }^{34}$ LANT. The big strip tease: female bodies and male power in the poetry of Sylvia Plath, p. 625.

${ }^{35}$ MULVEY. Visual pleasure and narrative fiction, p. 837.
} 
construction of representations. The fact that images conveyed by advertisements, movies, magazines etc. influence the way people think is an accepted conclusion nowadays. However, the dynamics between representation and desire should also be discussed in order to understand the way people's relations are affected.

According to Victoria De Grazia, in our culture people are led to believe they have the right to have what they want, and they should want more and more in order to be fulfilled. ${ }^{36}$ One of the problems that arises from this attitude is a growing tendency of an individual imposing his or her desire on others. Addressing the relation between gender and the consumer culture, de Grazia argues that "[s]exualized metaphors applied to the circulation and consumption of goods may be taken to stand for elusive social relations". ${ }^{37}$ De Grazia's argument addresses advertisements' incitement of desire as means of manipulating people's wants. Moreover, it argues that social relations are becoming more and more an "elusive” reflection of the consumption goods that are being sold. Advertisements are not a representation of individual's wants, but, instead, they serve as means of creating and manipulating them.

De Grazia also points out how the female body finds itself at the center of consumer culture as the major enticement to consumption. ${ }^{38}$ Men want the ideal woman, who does not actually exist outside make-believe world of advertisement, and women want to be like her. The stereotypes of desire are the theme of Plath's “The Applicant," in which the speaker describes in an ironic tone all the attributes the "ideal" woman should have in order to please a man: "Do you wear/ A glass eye, false teeth or a crutch,/ A brace or a hook,/ Rubber breasts or a rubber crotch// (...) A living doll, everywhere you look./ It can sew, it can cook, / It can talk, talk, talk."39 The objectification of the female body parts ("rubber breasts" and "a rubber crotch") can be read as a reference to the artificiality of the ideals that are constructed when it comes to what is desirable or not. This objectification also appears in other poems by Plath, such as "The Detective", ${ }^{40}$ in which instead of being constructed the female body is symbolically torn into pieces, each part referring to a form of oppressive demand on women:

\footnotetext{
${ }^{36}$ DE GRAZIA. Introduction, p. 2.

${ }^{37}$ DE GRAZIA. Introduction, p. 2.

${ }^{38}$ DE GRAZIA. Introduction, p. 7.

${ }^{39}$ PLATH. Collected poems, p. 221.

${ }^{40}$ PLATH. Collected poems, p. 208.
} 
It is a case of vaporization.

The mouth first, its absence reported

In the second year. It had been insatiable

And in punishment was hung out like brown fruit to wrinkle and dry.

The breasts next.

These were harder, two white stones.

The milk came yellow, then blue and sweet as water [.]

In the poem, the woman fails to fulfill the roles she is expected to, that of the mother, the lover and the housewife. The punishment to which the speaker refers is the vanishing of the woman, for, if she cannot be any of those things, it is implicit she has no use for and no identity at all: "No one is dead.// There is no body in the house at all". After the no-body is gone, what remains is "the smell of polish". Notice that this resource reminds the one that will come later in "Fever $103^{\circ}$," which is the disappearance of the female individual leaving behind the representatives of an oppressive identity.

In her reading of Spike Lee's Girl 9, a movie that narrates the life of a woman that works on a phone sex company, hooks discusses the fact the female sexuality is still today seen in relation to male desire. For instance, if a woman covers or undresses herself, it is also understood in relation to the effects this will have on male desire. Hooks sees Lee's movie as a criticism to the fact that female sexuality is based on women going "where the male imagination takes [them]", ${ }^{41}$ and that for women to fulfill their longings to be desired by men they have to "destroy parts of [themselves]". ${ }^{42}$ Hook's article is hopeful, even though it presents no easy solution. Female sexuality should not be defined in relation to a male perspective, and there will come a time when women "will not have to accommodate the desires of others". ${ }^{43}$

Plath presents in poems such as "The Applicant" and "Lesbos" women that are too concerned with mirroring their images according to the desire of men. These women do that by looking up at cultural role models, such as those portrayed by female movie stars - who at her time were exclusively directed by male directors - and trying hard to be attractive to men. "I am myself", the speaker says in "The Jailer", 44 "That is not enough". The main problem is that the real will never achieve the ideal. In a consumer society, in which, as bell hooks argues, "[t]he bodies of real women must be sacrificed on the

\footnotetext{
${ }^{41}$ HOOKS. Good girls look the other way, p. 483.

${ }^{42}$ HOOKS. Good girls look the other way, p. 481.

${ }^{43}$ HOOKS. Good girls look the other way, p. 486.

${ }^{44}$ PLATH. Collected poems, p. 226.
} 
patriarchal altar", ${ }^{45}$ women's sexualities are only seen in relation to the stereotypes patriarchal society has made available to them.

One of the reasons Plath's poetry depicts sexuality as a threat to individuality is the fact that many times it involves being subject to other people's fantasies. While alone, the speakers in her poems are free to imagine a world of their one, which does not happen when there are other people involved. Their main difficult, it seems, is that they are subjects of objectification as anything else. When discussing human sexuality, Jacques Lacan argues that fantasy is "the way in which subjects structure or organize their desire; it is the support of desire [and i]t is through fantasy that we learn how to desire and we are constituted as desiring subjects”. ${ }^{46}$ The problem is there is a thin line between fantasy and reality to the desiring subject. In a culture where the individual believes in the right to have and consume every want, ${ }^{47}$ fantasy escapes the limitations of the individual mind. This blurring of the limits between reality and fantasy creates a dangerous scenario when it comes to sexuality.

When it comes to illusions, no form of representation may be more addressed nowadays than the stereotypes perpetuated by propaganda. Mass media - cinema, magazines, and other types of discourses - and its power to establish normative representations appear in Plath's poetry as the source of dreams and longings but also as that which is responsible for the capitalist massification of desire and identity. In a culture where images are used to arouse the desire to consume, individual wants tend to collide against each other. The individual looses the boundaries between subjective and normative behaviors and wants.

It is important to remember that women also subscribe to particular social fictions of "womanhood”, but instead of engaging with their own desire, they are worried instead with being the object of male desire. In "Three Women", 48 for instance, even though the Second Voice is aware of the chauvinist world that surrounds her, she still wears stocking and high heels, two icons of enticement for male desire. The relation between image and desire, in fact, appears throughout the work of Plath as a constant source of anxiety. There is a need to be free from the pressure to be desirable, but there is also the will to be so,

\footnotetext{
${ }^{45}$ HOOKS. Good girls look the other way, p. 481.

${ }^{46}$ HOMER. Jacques Lacan, p. 86-87.

${ }^{47}$ DE GRAZIA. Introduction, p. 2.

${ }^{48}$ PLATH. Collected poems, p. 176.
} 
and, by doing that succumbing to male desire. Steven Gould Axelrod ${ }^{49}$ argues this conflict creates a need in Plath's speaker to separate mind and body, creative self from the social one. However, taking this duality to the realm of sexuality adds another matter to the way Plath's poems deal with gender: how much people's minds are governed by their bodies, and, moreover, how much people are defined by their desires.

\section{THE INDUSTRIOUS VIRGIN}

Psychoanalysis replaced the importance sexology had in the study of human sexuality by the beginning of the $20^{\text {th }}$ century. ${ }^{50}$ It had as its pioneer Sigmund Freud, who was followed by several others, the most notorious of them being Jacques Lacan. Through the concept of the "symbolic order" as the culture and the language that organize the individual's existence, ${ }^{51}$ Lacan offers a view on human sexuality as highly dependent upon culture instead of biology and claims that "desire is cultural ... and [w]hat we find desirable is generated by the norms and values of the culture in which we live, even if it can focus on what that culture presents as perverse or unhealthy"52.

Lacan's view on sexuality is the basis for Butler's analysis on sexuality and how it is shaped by the way people read their own bodies and, moreover, how people read each other's bodies. Following Lacan's studies, Butler argues in her work that this reading must necessarily happen inside the possibilities and the labels of normality existent within one's culture. Sexuality, as individuality, is constructed through a relationship net in which one is always projecting oneself in relation to external forces. Hence, Butler asks: "What is the relation between desire and recognition, and how is it that the constitution of the subject entails a radical and constitutive relation to alterity?"53 Sara Salih summarizes Butler's approach to desire and subjectivity in these words:

To put this another way, the subject can only know itself through another, but in the process of recognizing itself and constituting its own self-consciousness it must overcome or annihilate the Other, otherwise it places its own existence at risk (SD: 37). Desire, in other words, is

\footnotetext{
${ }^{49}$ AXELROD. The mirror and the shadow: Plath's poetics of self-doubt, p. 290.

${ }^{50}$ BRISTOW. Sexuality, p. 34.

${ }^{51}$ MALPAS. The postmodern, p. 68.

${ }^{52}$ MALPAS. The postmodern, p. 68.

${ }^{53}$ BUTLER. Subjects of desire: hegelian reflections in twentieth-century France, p. xiv.
} 
tantamount to the consumption of the Other. ${ }^{54}$

Butler's argument of the subject knowing itself only through another is an idea that comes from Hegel's famous example of lordship and bondage in which the master is only a master if it has a relation of ownership with the slave and vice-versa. ${ }^{55}$ This analogy is an attempt to understand the relation between the subject's self-consciousness and the necessary adaptation process it goes through to exist and interact in an external plane, which can be seen as culture, language, society etc. Hegel treats both the Self and the Other as two different parts of the subjects' constitution, and both are endlessly battling over supremacy, while the self wants autonomy and to impose itself on the Other. The Other is the one that recognizes that only through adaptation of the Self the subject is able to interact in a community. ${ }^{56}$

Hegel's analogy has been highly influential, and in fact it is a model of subjectivity that serves the purpose of understanding the oppressive quality desire can assume. For Butler, desire is the desire to impose the Self into the Other, which can be read as the individual's will to see his wants concretized in the external world. In this context, the Other may easily assume the form of another subject, who must be conquered in order for the Self's autonomy to be imposed. This reading becomes an important model in literary representations of desire and sexuality. Moreover, it becomes a model to understand the dynamics of sexual violence in gender relations.

Violence and sexuality create a general feeling of inescapability in Plath’s poems, as if there is no way to escape the oppression of sexual definitions. In Plath's "The Bee Meeting”, 57 the speaker is prepared to join a society of bee keepers. The ritual could be seen as a metaphor for any other form of social initiation. The speaker is afraid because, contrary to all others in there, she is not protected in her "sleeveless summer dress" that leaves parts of her body uncovered and henceforth passive to the aggression of the bees. By "turning into silk" - light, almost transparent -, she hopes to become unnoticed and, henceforth, to hide her fear. The figure of the surgeon, that is repeated in poems such as “Surgeon at 2 a.m.” and "Lady Lazarus”, appears as the threatening and powerful male figure that is current in Plath's poems.

\footnotetext{
${ }^{54}$ SALIH. Judith Butler, p. 26.

${ }^{55}$ SALIH. Judith Butler, p. 27.

${ }^{56}$ SALIH. Judith Butler, p. 27.

${ }^{57}$ PLATH. Collected poems, p. 211.
} 
Even though people are there to extract the honey from the bee hive, the speaker acts as if the "operation” was going to take place in her own self. "I could not run without having to run forever”, she says as if all that ritual is unavoidable and she cannot do much but to be an spectator and "stand very still". When the hive is finally opened, the "villagers" hunt for the queen bee, which the speaker suddenly identifies herself with. What connects the speaker to the hive and the queen is the same thing: being passive of invasion. This comparison is clearer when the white hive is described as being "snug as a virgin,/ Sealing off her brood cells, her honey, and quietly humming”. The hive is compared to the female body, in which the sex is passive of invasion and violation.

Nevertheless, more than accusing the violence of male sexuality, Plath also exposes the pressure women fell to withdraw from desire. Either they are promiscuous or innocent, and this is evident in poems that depict male and female sexual relations under those line of female/passiveness (and even fear) from the male assertive sexuality. In "Pursuit”, the "panther” that pursuits the female speaker is described as a threatening man sexually aroused:

The black marauder, hauled by love

On fluent haunches, keeps my speed.

... Bright those claws that mar the flesh

And hungry, hungry, those taut thighs.

His ardor snares me, lights the trees,

And I run flaring in my skin;

What lull, what cool can lap me in

When burns and brands that yellow gaze? ${ }^{58}$

The speaker's voice presents a mixture of fear, victimization and attraction. After long running, she gives in to the beast:
I hurl my heart to halt his pace,
To quench his thirst I squander blood;
He eats, and still his need seeks food,
Compels a total sacrifice.
His voice waylays me, spells a trance [.]

There is a "secret want" in the speaker's attitude. Even though she locks herself in "the tower of [her] fears", she still hears the threatening steps of the panther "coming up and up the stairs”. The theme of insatiability reappears in later works, but with a much graver and critical tone. Poems such as “The Jailer", the Bee Poems and "Fever 103"” are

\footnotetext{
${ }^{58}$ PLATH. Collected poems, p. 22.
} 
voiced by women who had given in to the threat and are now struggling to regain power over their bodies and their sexuality. There is no desire or attraction, but fear, repulsion and resentment. However, it is important to notice still in the early poetry of Plath that the threat of sexual desire is not only due to physical menace, but in poems such as "Virgin in a Tree" the guilt that has long been imposed of female sexuality is also to blame for this passive role women assume when it comes to gender/sexual relations. The subject of guilt, history and women's sexual repression will be developed until Plath's final poems.

The association between purity and female sexuality is criticized in poems such as Plath's "Virgin in a Tree",59 in which the speaker criticizes the tradition of blaming women for their own sexuality. The poem cites Helen of Troy and Eve as a manner of discussing how throughout history women have been considered the ones responsible for the mistakes of men, who are considered to be driven by desire due to women's inability to repress their own sexuality. Patrick D. Hopkins discusses how different the imposed relation towards sexuality is between men and women:

The connection between women's responsibilities and male psychology also got cashed out in regard to sex. We were specifically taught that girls and women had the power to control their sex drive - including the ability virtually to shut it on or off at will. Boys and men, on the other hand, lacked such ability, and although they were clearly held morally responsible for their own behaviors, they were much more susceptible to sexual impulse[.] $]^{60}$

According to Hopkins, this belief has served to put on women all responsibility when it comes to sex. Since men are thought of as not capable of controlling their sexual impulses, it is women's responsibility "to resist physical contact or suggestive behavior that might inflame their suitors". ${ }^{1}$ Still today, and it is not unusual, allegations of being “incited” by a woman is used as justification for rapes.

However, it remains the question whether the subject can exist without such social "garments", for, in the end of Plath's poem, the selves are the ones to dissolve, and the petticoat is the one that remains. If the comma indicates a separation between the selves and the petticoat, what can be read as a separation between identity and sexuality, could

\footnotetext{
${ }^{59}$ PLATH. Collected poems, p. 81.

${ }^{60}$ HOPKINS. How feminism made a man out of me: the proper subject of feminism and the problem of men, p. 35.

${ }^{61}$ HOPKINS. How feminism made a man out of me: the proper subject of feminism and the problem of men, p. 35.
} 
the poem be suggesting the impossibility for women to conciliate sexuality and an empowering individuality? Much of the feminist criticism on the body has as its underlying matter the autonomy of female sexuality. According to Julian Wolfreys, when it comes to the subject of the body feminist history has showed ambivalence: while some believe the body to be the source of women's oppression, others view it as "the locus of a specifically female power". ${ }^{2}$ Similarly to the disagreements involving feminism and pornography, the subject of the body is filled with controversies around the restraints and/or freedom it offers women. Even nowadays, after so many achievements of feminism, it is difficult to get to a consensus. Is a naked female body a symbol of empowerment or a reinforcement of its submissiveness in a patriarchal society? Is the only way to escape this submissive body by symbolically extinguishing it completely as the speaker in Plath's poem does?

The voices that narrate Plath's poetry are not comfortable with being seen in the third person and rather remain in their first person selves. This conflict is also discussed in her poetry in terms of public versus private and society versus self. However, when it comes to sexuality this conflict appears in people's relations themselves. The desire to subjugate the other according to one's own makes sexuality is not only a threat to one's individuality but also a source of violence in people's relationships.

In this sense, Plath's poetry is critical when it comes to sexuality as an expression of individuality and as a form of emotional connection between people, even though her speakers still long for those interpersonal connections. The main problem lay in how the matter of sexuality is portrayed and how these constructed ideals influence the way people relate to each other. In a culture based on gender inequality, sexuality manifests itself in oppressive, and even violent, ways, which is a contradiction to the notion that it should bring people closer together. Instead of being attached to the ideal of intimacy, sexuality is seen in the poetry of Plath as a tool to reinforce the artificial demands of a culture based on constructed images of what people should be. What her poetry suggests is not the negation of sexuality, but a different way, more individual and less limited, of representing it. Instead of a social matter, Plath's poetry claims sexuality should be an individual one, even though there is the awareness that the line that separates both is a very thin and fragile one.

\footnotetext{
${ }^{62}$ WOLFREYS. Critical keywords in literary and cultural theory, p. 25.
} 


\section{RESUMO}

Este trabalho analisa a maneira na qual os poemas de Sylvia Plath retratam as relações gênero e, mais especificamente, como a construção de gênero baseada em hierarquia e desigualdade se torna um impedimento à relação harmoniosa e, principalmente, ao amor nas relações interpessoais. Nos poemas analisados, os ideais de amor e intimidade são sempre afastados por consequência da desigualdade entre gêneros, que, apesar de grandes progressos nessa área, ainda hoje continua a servir de base para as relações entre as pessoas. Nesse contexto, a poesia de Plath retrata a sexualidade como uma ferramenta central na perpetuação da dominância masculina e submissão feminina, fato que dificulta ainda mais as relações entre homens e mulheres.

\section{PALAVRAS-CHAVE}

Poesia, gênero, sexualidade

\section{REFERENCES}

AXELROD, Steven Gould. The mirror and the shadow: Plath's poetics of self-doubt. Contemporary Literature, v. 26, n. 3, p. 286-301, 1985.

BRISTOW, Joseph. Sexuality. London: Routledge, 1997.

BRITZOLAKIS, Christina. Sylvia Plath and the theatre of mourning. Oxford: Oxford University Press, 2000.

BUTLER, Judith. Bodies that matter: on the discursive limits of sex. London: Routledge, 1993.

BUTLER, Judith. Subjects of desire: hegelian reflections in twentieth-century France. New York: Columbia University Press, 1987.

CARTER, Angela. The sadeian woman: an exercise in cultural history. London: Virago, 1979.

DE GRAZIA, Victoria. Introduction. In: DE GRAZIA, Victoria; FURLOUGH, Ellen. (Org.). The sex of things: gender and consumption in historical perspective. Los Angeles: University of California Press, 1996. p. 1-11.

DE LAURETIS, Teresa. Technologies of gender: essays on theory, film, and fiction (Theories of representation and difference). Bloomington: Indiana University Press, 1987.

FAUSTO-STERLING, Anne. Sexing the body: gender politics and the construction of sexuality. New York: Basic Books, 2000.

FOUCAULT, Michel. The history of sexuality: an introduction. Trans. Robert Hurley. 
New York: Vintage Books, 1976. v. I.

GIDDENS, Anthony. The transformation of intimacy: sexuality, love and eroticism in modern societies. Stanford: Stanford University Press, 1992.

HOMER, Sean. Jacques Lacan. London: Routledge/Taylor \& Francis Group, 2005.

HOOKS, bell. Good girls look the other way. In: CORNELL, Drucilla (Org.). Feminism and pornography. Oxford readings in feminism. Oxford: Oxford University Press, 2000. p. 477-486.

HOPKINS, Pratick D. How feminism made a man out of me: the proper subject of feminism and the problem of men. In: DIGBY, Tom (Org.). Men doing feminism. New York: Routledge, 1998. p. 33-56.

LANT, Kathleen Margaret. The big strip tease: female bodies and male power in the poetry of Sylvia Plath. Contemporary Literature, v. 34, n. 4, p. 610-669, 1993.

MALPAS, Simon. The postmodern. New York: Routledge, 2005.

MULVEY, Laura. Visual pleasure and narrative fiction. In: BRAUDY, Leo; COHEN, Marshall (Org.). Film theory and criticism: introductory readings. New York: Oxford UP, 1999. p. 833-44.

O’TOOLE, Laura; SHIFFMAN, Jessica R. Preface: conceptualizing gender violence. In: . EDWARDS, Margie L. Kiter (Org.). Gender and violence: interdisciplinary perspectives. New York: New York University Press, 1997. p. xi-xiv.

PLATH, Sylvia. Collected poems. Hughes, Ted (Org.). New York: HarperPerennial, 1992.

SALIH, Sara. Judith Butler. London: Routledge/Taylor \& Francis Group, 2002.

STOLLER, Robert. Sex and gender: on the development of masculinity and femininity. London: Science House, 1968.

WOLFREYS, Julian. Critical keywords in literary and cultural theory. New York: Palgrave/Macmillan, 2004. 